\title{
Work Environment Characteristics as Determinants of Work to Family Conflict Among Working Females, Egypt
}

Hanaa Zayed ( $\nabla$ hanazayed55@yahoo.com )

Tanta University Faculty of Medicine

Ibrahim Kabbash

Tanta University Faculty of Medicine

Rania Elsalamy

Tanta University Faculty of Medicine

Sanaa Abdo

Tanta University Faculty of Medicine

\section{Research Article}

Keywords: Work Environment Characteristics, Work to Family Conflict, Female employees

Posted Date: February 16th, 2021

DOl: https://doi.org/10.21203/rs.3.rs-200593/v1

License: (c) (i) This work is licensed under a Creative Commons Attribution 4.0 International License.

Read Full License

Version of Record: A version of this preprint was published at Environmental Science and Pollution Research on April 12th, 2021. See the published version at https://doi.org/10.1007/s11356-021-13884-9. 


\section{Abstract}

\section{Background}

Positive work practice environment is the corner stone for control and relieving of work to family conflict (WFC).

\section{Objectives}

o determine the prevalence of work to family conflict and to study the relation between work to family conflicts and work environment characteristics among full-time female employees at Tanta University Medical Campus.

Methods

A cross sectional study was carried among female employees working in the five Faculties that present at Tanta University Medical Campus. A total of 442 female workers were recruited. Data were collected using a self-administered questionnaire including personal characteristics, work related data and home responsibilities. Job characteristics scales, work to family and family to work spillovers scales were used to study their correlation.

Results

Participants' mean age was $39.87 \pm 10.07$ years. Significant positive correlation was detected between; skills discretion and both of positive work to family and family to work spillovers $(r=0.361, r=0.288, P=0$. 0.001 respectively), similar relations were reported regarding decision authority, coworkers support and supervisors support. The negative work to family and family to work spillovers significantly increased by increasing in work demands $(r=0.0 .315, r=0.218, P=0.0 .001$ respectively). Significant and negative correlations were found between each of skills discretion \& supervisors support scales and the negative impact of family to work spillover $(r=-0.130 ; P=0.006, r=-0.167 ; P=0.001$, respectively).

Conclusion

Positive work practices environment is a significant determinant to prevent and control work to family conflict.

\section{Introduction}

Family-friendly work environments help positive outcomes for workforces, motivating them at work and increasing positive mood at home too [Van Steenberg \& Ellemers, 2009, Sanz_Vergel et al., 2015]. In contrast, non- motivating work atmospheres have been related to troubles in family running that may lead to poor outcome of employee [Anand et al., 2014]. Supporting a positive spillover between work and family is consequently critical for health and welfare of employee [Carvalho \& Chamberl, 2014, Russo, 
2015]. Role pressures from family and work fields are mutually incompatible and turn into stressors [Greenhaus and Butell, 1985].

Job stress is progressively predictable as one of the most serious occupational hazards that decreasing workers' productivity, satisfaction, and increasing turnover and absenteeism [Gianakos, 2000]. Feeling unsecure due to the working environment leading to job stress. Work-family conflicts and work overload is a well-known cause of stress [Stamper \& Johike, 2003]. Stressors at work such as personalprofessional conflicts and work overload are identified to generate boredom in work that spills over into the family [Fu \& Shaffer, 2001].

All over the world, women actively participate in work market to support their families' economy and to achieve their professional career. Nearly all women employed in full-time work, are energetic contributors in labor force. However, still preserving their customary roles and principal accountability for housework, childcare, possibly the care of the elderly parents, or a family member with special needs adding to stresses of work demands. Conflicts appears once performance in one role generates an incapability to perform the other role sufficiently [Ajala, 2017]. Work-family-conflict (WFC) means the effect of work on the family, whereas family-work conflict (FWC) reports the effect of the family on the work activities [Fu \& Shaffer, 2001]. These conflicts have serious negative effect on both women and work leading to decrease in work performance, job dissatisfaction, psychological suffering, and marital frustration [Ajala, 2017].

Numerous studies stated that employed women have higher levels of family- work conflict than employed men, particularly women involved in management work [Apperson e al., 2002- Yavas et al, 2008]. An employed woman experience opposing role expectations while she is at work and home. At work, she is anticipated to be energetic, dynamic, competitive, creative and act in a professional manner. At home, she is predicted to be sensitive, sweet, soft and domesticated [Misra, 1998]. These conflicts lead to family unhappiness and reduce the level of job performance among female employees. Consequently, loss at both sides will occur; the home and the workplace [Ajala, 2017]. Correspondingly, as society is not isolated from any organizations and work place, this conflict will disturb the society in different ways; lower quality services and lower standards of performance.

In Egypt, The Central Agency for Mobilization and Statistics stated that women are heads of $18.1 \%$ of households. Women aged $15-64$ years constitute $25 \%$ of employed work force. When accounting for their contribution to the informal sector and their unpaid domestic work, the percentage becomes far greater [Egypt Today, 2020]. The objectives of this study were to determine the prevalence of work to family conflict and to study the relation between work to family conflicts and work environment characteristics among full-time female employees at Tanta University Medical Campus.

\section{Subject And Methods}

This cross-sectional study was conducted during September and October 2019 at Tanta University Medical Campus hosting five faculties; Medicine, Nursing, Dentistry, Pharmacy and Faculty of Science. Communications were made with faculties' Deans to get their approval and co-operation. 
The sample was obtained by convenience non-probability method and included 442 full-time female employees out of 645 who were in service during the period of the study. Female employees with work duration less than one year were excluded. The study was approved by Tanta Faculty of Medicine Research Ethics Committee and informed consent was obtained from all participants.

Information was collected through a pre-designed self-administered questionnaire which included the basic demographic profile as age, qualifications, marital status, number of household members, duration of marriage, number offspring, monthly income, experience in current job, caring for a person with special needs and home responsibilities.

\section{Work to family and family to work spillover scale}

it included 4 domains; positive work to family spillover (4 items), negative work to family spillover (4 items), positive family to work spillover ( 4 items), negative family to work spillover ( 4 items). All items were rated on a 5 -point scale, ranging from $1=$ all the time to $5=$ never. [National Study of Health and Wellbeing, 2004]

\section{Job characteristics}

it included five domains; skill discretion (3 questions), decision authority scale (6 questions), work demands scale (5 questions), coworkers support (2 questions) and supervisors support (3 questions). The responses were rated on 5- points scale as; 1 all the time; 2 most of the time; 3 sometimes; 4 rarely; 5 never. [National Study of Health and Wellbeing, 2004]

Validity of the questionnaire was checked by five experts, who reviewed the questionnaire for clarity, relevance, comprehensiveness, understanding, and applicability. Reliability was estimated by a Cronbach's test and its result was equal to 0.82 .

Data analysis was performed using Statistical Package for Social Sciences (SPSS) version 21. Qualitative data were presented as number and percent. Quantitative data were presented as mean and standard deviation (SD). Pearson's correlation was used to measure the strength and direction of the relationship between quantitative variables and the level of significance was adopted at $p \leq 0.05$.

Ethical considerations: the paper was approved by the internal review board of Faculty of Medicine, Tanta University. Written consent was taken form study participants before data collection which was totally anonymous.

\section{Results}

Four hundred forty-two full-time female employees were recruited in this study with a mean age of 39.87 \pm 10.07 years and a mean duration of work of $11.77 \pm 9.6$ years. Most of participants $(78 \%)$ had bachelor and diploma degrees and $79.2 \%$ were married. Approximately two third of them (64.6\%) had 2 or 3 offspring aged less than 20 years. The monthly income was not enough for more than one half of 
participants (53.8\%). Among participants, $82.4 \%$ were responsible for all home responsibilities and 33.7\% had support for these responsibilities while $29.9 \%$ took care for a person with special needs (Tables 1,2$)$. 
Table 1

Sociodemographic characteristics of participants

\begin{tabular}{|c|c|c|}
\hline Variables & Number $(n=442)$ & $\%$ \\
\hline \multicolumn{3}{|l|}{ Age in years: } \\
\hline $20-$ & 68 & 15.4 \\
\hline $30-$ & 174 & 39.4 \\
\hline $40-$ & 95 & 21.5 \\
\hline $50-60$ & 105 & 23.8 \\
\hline \multicolumn{3}{|l|}{ Qualifications: } \\
\hline Diploma & 148 & 33.5 \\
\hline Bachelor & 197 & 44.6 \\
\hline Master degree & 38 & 8.6 \\
\hline Doctorate degree & 23 & 5.2 \\
\hline Others & 36 & 8.1 \\
\hline \multicolumn{3}{|l|}{ Marital status: } \\
\hline Single & 49 & 11.1 \\
\hline Married & 350 & 79.2 \\
\hline Divorced & 18 & 4.1 \\
\hline Widow & 25 & 5.7 \\
\hline \multicolumn{3}{|c|}{ Number of household members: } \\
\hline$<3$ & 47 & 10.6 \\
\hline 3 & 93 & 21.0 \\
\hline 4 & 129 & 29.2 \\
\hline 5 & 109 & 24.7 \\
\hline $6+$ & 64 & 14.5 \\
\hline \multicolumn{3}{|c|}{ Duration of marriage in years $(n=393)$ : } \\
\hline$<5$ & 28 & 7.1 \\
\hline $5-$ & 93 & 23.7 \\
\hline $10-$ & 61 & 15.5 \\
\hline $15+$ & 211 & 53.7 \\
\hline
\end{tabular}




\begin{tabular}{|c|c|c|}
\hline Variables & Number $(n=442)$ & $\%$ \\
\hline \multicolumn{3}{|c|}{ Number of off spring: $(n=393)$} \\
\hline 0 & 25 & 6.4 \\
\hline 1 & 51 & 13.0 \\
\hline 2 & 151 & 38.4 \\
\hline 3 & 103 & 26.2 \\
\hline $4+$ & 63 & 16.0 \\
\hline \multicolumn{3}{|c|}{ Age of youngest sibling in years $(n=362)$} \\
\hline$\leq 2$ & 67 & 18.5 \\
\hline $3-5$ & 69 & 19.1 \\
\hline $6-12$ & 97 & 26.8 \\
\hline $13-19$ & 61 & 16.9 \\
\hline $20+$ & 68 & 18.8 \\
\hline
\end{tabular}


Table 2

Work related characteristics of participants

\begin{tabular}{|c|c|c|}
\hline Variables & Number(n = 442) & $\%$ \\
\hline \multicolumn{3}{|l|}{ Monthly income: } \\
\hline Not enough & 238 & 53.8 \\
\hline Just enough & 180 & 40.7 \\
\hline Enough and saving & 24 & 5.5 \\
\hline \multicolumn{3}{|l|}{ Total experience in years: } \\
\hline$<5$ & 53 & 12.0 \\
\hline $5-$ & 115 & 26.0 \\
\hline $10-$ & 100 & 22.6 \\
\hline 15- & 46 & 10.4 \\
\hline $20+$ & 128 & 29.0 \\
\hline \multicolumn{3}{|l|}{ Experience in current job: } \\
\hline$<5$ & 101 & 22.9 \\
\hline $5-$ & 147 & 33.3 \\
\hline $10-$ & 72 & 16.3 \\
\hline 15- & 33 & 7.5 \\
\hline $20+$ & 89 & 20.1 \\
\hline \multicolumn{3}{|l|}{ Have house responsibilities } \\
\hline None & 15 & 3.4 \\
\hline Some & 63 & 14.3 \\
\hline All & 364 & 82.4 \\
\hline Caring for a person with special needs & 132 & 29.9 \\
\hline Having support of house responsibilities & 149 & 33.7 \\
\hline Having supportive family member in hard days & 337 & 76.2 \\
\hline \multicolumn{3}{|l|}{ Need vacation to care for family member } \\
\hline Many days & 105 & 23.8 \\
\hline Sometimes & 259 & 58.6 \\
\hline Rarely & 78 & 17.6 \\
\hline
\end{tabular}


According to the degree and impact of spillover of one role identity over the other, about half of participants had either moderate positive $(52.9 \% \& 51.6 \%)$ or moderate negative $(50.5 \% \& 48.0 \%)$ degree of work to family and family to work spillovers respectively. Nearly one third of female employees (34.6\%) had high degree of positive family to work spillover while only $14 \%$ had high positive work to family spillover. Regarding job characteristics scales, more than half of participants $(55.9 \%)$ had moderate degree of skills discretion and $43.4 \%$ reported to have low degree of decision authority in planning their work environment. Moderate level of work demands was reported by $69.5 \%$ and $60 \%$ reported moderate degree of coworkers and colleagues support while $53.2 \%$ of female employees reported moderate supervisors and management support (Table 3).

Table 3

Distribution of participants by work-family-work conflicts severity and work characteristics

\begin{tabular}{|lllllll|}
\hline Variable & Low & \multicolumn{4}{l}{ Moderate } & \multicolumn{2}{l|}{ High } \\
\cline { 2 - 8 } & $\mathbf{n}$ & $\%$ & $\mathbf{n}$ & $\%$ & $\mathbf{n}$ & $\%$ \\
\hline Positive work to family spillover & 146 & 33.0 & 234 & 52.9 & 62 & 14.0 \\
\hline Negative work to family spillover & 147 & 33.3 & 223 & 50.5 & 72 & 16.3 \\
\hline Positive family to work spillover & 61 & 13.8 & 228 & 51.6 & 153 & 34.6 \\
\hline Negative family to work spillover & 196 & 44.3 & 212 & 48.0 & 34 & 7.7 \\
\hline Skills discretion & 113 & 25.6 & 247 & 55.9 & 82 & 18.6 \\
\hline Decision authority & 192 & 43.4 & 207 & 46.8 & 43 & 9.7 \\
\hline Work demands & 90 & 20.4 & 307 & 69.5 & 45 & 10.2 \\
\hline Coworkers support & 86 & 19.5 & 265 & 60.0 & 91 & 20.6 \\
\hline Supervisors support & 100 & 22.6 & 235 & 53.2 & 107 & 24.2 \\
\hline
\end{tabular}

Significant positive correlation was detected between positive work to family spillover and number of children of participants $(r=0.103, P=0.041)$. The relation was significant and negative between negative work to family spillover and monthly income of participants $(r=-0.102, p=0.032)$. Negative family to work spillover was significantly decreased as the age of participants increased $(r=-0.095, p=0.045)$. Significant positive correlation was found between decision authority at work and monthly income $(r=$ $0.169, p=0.001)($ Table 4). 
Table 4

Correlation of age, number of children \& income with work-family conflicts and work characteristics among participants

\begin{tabular}{|lllllll|}
\hline Variables & \multicolumn{2}{l}{ Age in years } & Number of children & \multicolumn{2}{l|}{ Monthly income } \\
\cline { 2 - 7 } & $\mathbf{r}$ & $\mathbf{p}$ & $\mathbf{r}$ & $\mathbf{p}$ & $\mathbf{r}$ & $\mathbf{p}$ \\
\hline Positive work to family spillover & 0.076 & 0.112 & 0.103 & $0.041^{*}$ & 0.042 & 0.384 \\
\hline Negative work to family spillover & -0.081 & 0.088 & 0.003 & 0.954 & -0.102 & $0.032^{*}$ \\
\hline Positive family to work spillover & -0.034 & 0.477 & 0.030 & 0.551 & 0.046 & 0.335 \\
\hline Negative family to work spillover & -0.095 & $0.045^{\star}$ & 0.045 & 0.378 & 0.020 & 0.671 \\
\hline Skills discretion & -0.037 & 0.438 & 0.036 & 0.482 & 0.040 & 0.399 \\
\hline Decision authority & -0.003 & 0.955 & 0.052 & 0.301 & 0.169 & $0.001 *$ \\
\hline Work demands & -0.093 & 0.051 & 0.025 & 0.624 & -0.075 & 0.114 \\
\hline Coworkers support & 0.001 & 0.992 & 0.024 & 0.632 & 0.015 & 0.758 \\
\hline Supervisors support & -0.046 & 0.336 & -0.029 & 0.563 & 0.007 & 0.889 \\
\hline *Significant & & & & & & \\
\hline
\end{tabular}

Significant good positive correlation was observed between positive work to family spillover and skills discretion $(r=0.361)$, decision authority $(r=0.362)$. On the other hand, there was week significant positive correlation between work to family spillover and coworkers support and supervisors support $(r=0.163$ and 0.157 , respectively). Negative work to family spillover significantly correlated with work demand $(r=$ $0.315, p=0.001$ ). Positive family to work spillover showed good positive significant correlation with all work characteristics except for work load. Negative family to work spillover showed significant negative correlation with both skills discretion $(r=-130)$ and supervisors support $(r=-0.167)$. The correlation between negative family to work spillover was significantly positive for work demands $(r=0.218)$. (Table 5) 
Table 5

Correlation between work characteristics and family-work conflict among studied female employees

\begin{tabular}{|c|c|c|c|c|c|c|c|c|}
\hline \multirow[t]{2}{*}{ Variables } & \multicolumn{2}{|c|}{$\begin{array}{l}\text { Positive work to } \\
\text { family spillover }\end{array}$} & \multicolumn{2}{|c|}{$\begin{array}{l}\text { Negative work to } \\
\text { family spillover }\end{array}$} & \multicolumn{2}{|c|}{$\begin{array}{l}\text { Positive family to } \\
\text { work spillover }\end{array}$} & \multicolumn{2}{|c|}{$\begin{array}{l}\text { Negative family to } \\
\text { work spillover }\end{array}$} \\
\hline & $r$ & p & $r$ & p & $\mathbf{r}$ & p & $r$ & p \\
\hline $\begin{array}{l}\text { Skills } \\
\text { discretion }\end{array}$ & 0.361 & $0.001 *$ & 0.007 & 0.883 & 0.288 & $0.001^{*}$ & -0.130 & $0.006 *$ \\
\hline $\begin{array}{l}\text { Decision } \\
\text { authority }\end{array}$ & 0.362 & $0.001 *$ & -0.019 & 0.692 & 0.249 & $0.001^{*}$ & 0.086 & 0.071 \\
\hline $\begin{array}{l}\text { Work } \\
\text { demands }\end{array}$ & 0.023 & 0.631 & 0.315 & $0.001^{\star}$ & 0.046 & 0.330 & 0.218 & $0.001^{*}$ \\
\hline $\begin{array}{l}\text { Coworkers } \\
\text { support }\end{array}$ & 0.163 & $0.001 *$ & 0.010 & 0.841 & 0.238 & $0.001^{*}$ & 0.059 & 0.212 \\
\hline $\begin{array}{l}\text { Supervisors } \\
\text { support }\end{array}$ & 0.157 & $0.001^{*}$ & -0.072 & 0.133 & 0.207 & $0.001^{*}$ & -0.167 & $0.001 *$ \\
\hline
\end{tabular}

\section{Discussion}

The present study reported that the negative family to work spillover was significantly decreased as the age of female employees increased. This result was concurrent with a study conducted by Winslow (2005) who found that older parents suffer less work-family conflict than younger ones. This may be because older parents usually possess more resources to deal with the various accountabilities of work and family. They are also in established and stable positions in their lives, and are economically more independent than younger parents are. Consequently, the increase in the age of parents may be associated with decreasing in work-family conflict.

In the present study, significant positive correlation was detected between skills discretion and both of positive work to family and family to work spillovers. Similar relations were also reported regarding other job characteristics scales included; decision authority, coworkers support and supervisors support. We stated that the negative work to family and family to work spillovers significantly increased by increasing work demands. Significant and negative correlations were found between each of skills discretion \& supervisors support scales and the negative family to work spillover. These findings were supported by Taylor et al, 2009 who found that supervisor support, climate of work and job characteristics impact work-family conflict. Also other researchers showed that establishments, through the provision of job resources such as sense of control, job autonomy, coworker and supervisor support, can aid employees to recognize a positive spillover between work and family [Barnett \& Hyde, 2001 - Odle-Dusseau, 2012].

In the current study, a significant positive correlation was detected between decision authority scale items as (e.g. control the amount of time you spend on tasks) and positive work to family and family to work spillovers. Also the negative work to family spillover significantly increased by increasing in work 
demands. These results were in line with other studies that indicated that employees applying such work arrangements as malleable schedules found to be more satisfied in their work and experienced less workfamily conflict, and that their time and relations with their children had improved [Lee et al., 2002]. Demands of work and resources, for example the number of worked hours and time limitations are important causes connecting to work-family conflict. It is consequently important for establishments to not only encourage flexibility as work hours and schedules, but also promote other forms of employee autonomy that would assist employees to manage their work-family conflict [Voydanoff, 2004].

Other study reported that work demands are predictable to be salient in influencing work-family conflict principally the work interference with the family dimensions because they accompanied by processes that hinder the performance of family roles needed for contribution in family activities [Voydanoff, 2004]. This study showed a significant positive correlation between positive work to family spillover and supervisor support. These findings supported by previous researches on supervisor support and workfamily enrichment. Authors reported that a family supportive supervisor appears to increase employees' energy, enthusiasm and positive attitude at work, which empowers employees to transfer knowledge and learned skills at work to their families. Supportive supervisor looks to aid establishments to produce high engaging work environments and create atmospheres of psychological satisfaction among employees [Siu et al, 2010; Straub et al, 2017].

\section{Concolusion}

All studied participants had work-family conflicts of different degrees of severity, the sources of conflict are dependent on the availability of various support systems within the family and the organization where they work. Significant positive correlation was detected between work characteristics as; skills discretion, decision authority, coworkers support and supervisors support and both of positive work to family and family to work spillovers. Negative work to family and family to work spillovers significantly increased by increasing in work demands. Significant and negative correlations were found between each of skills of discretion \& supervisors support scales and the negative impact of family to work spillover

\section{RECOMMENDATIONS}

Work-family conflict can be reduced through creating family supportive and comfortable work environments, as flexible work schedules, child and elder care services, adjustment of work demands and reinforcement of decision authorities.

\section{Declarations}

\section{Ethical approval}

This study was approved by Tanta Faculty of Medicine Research Ethics Committee (REC).

\section{Consent to participate}


Formal written consent was taken from all study participants.

\section{Consent to publish}

Not applicable.

\section{Authors contributions}

Hanaa Abdelaziz Zayed participated in data collection, statistical analysis and was a major contributor in writing and revision of the manuscript". "Ibrahim Ali Kabbash was responsible for the concept of the paper, statistical analysis of data and shared in writing and revision of the manuscript. Rania Moustafa El-Sallamy participated in data collection, statistical analysis and writing of the paper. Sanaa Abd Elfatah Abdo was a major contributor in preparation of questionnaire and data collection.

\section{Funding}

Not applicable.

\section{Conflicts of interest}

The authors declare no conflicts of interest.

\section{Availability of data and materials}

Not available

\section{References}

1. Ajala, E. M. (2017). Work-family-conflict and family-work-conflict as correlates of job performance among working mothers: implications for industrial social workers. AJSW, Volume 7 (1).

2. Anand, S., Vidyarthi, P., Singh, S., \& Ryu, S. (2014). Family interference and employee dissatisfaction: Do agreeable employees better cope with stress? Human Relations, 68,691-708. Doi: $10.1177 / 0018726714539714$.

3. Apperson, M., Schmidt,H., Moore, S., Grunberg, L., and Greenberg, E. (2002). Women managers and the experience of work- family conflict. American Journal of Undergraduate Research, 1, 9-16.

4. Barnett, R.C., \& Hyde, J.S. (2001). Women, men, work, and family: An expansionist theory. American Psychologist, 56, 781-796.

5. Carvalho, V. S., \& Chambel, M. J. (2014). Work-to-family enrichment and employees' wellbeing: High performance work system and job characteristics. Social Indicators Research, 119, 373-387. Doi: 10.1007/s11205-013-0475-8.

6. Egypt Today. What Women Give. Available at: https://www.egypttoday.com/Article/15/15549/WhatWomen-Give .last assessed on January 30- 2020.

7. Fu, C.K., and Shaffer, M.A (2001). The tug of work and family; Direct \& indirect domain specific determinants of work-family conflict. Personnel review, Vol.3, No.5, pp 502-22. 
8. Gianakos, I (2000).Gender roles and coping with work stress, sex-roles, 42(11-12), 1059-1079.

9. Greenhaus, J. H., \& Beutell, N. J. (1985). Sources of conflict between work and family roles. Academy of management review, 10, 76-88.

10. Lee, M.D., MacDermid, S.M., Williams, M.L., Buck, M.L., \& Leiba-O’Sullivan, S. (2002). Contextual factors in the success of reduced-load work arrangements among managers and professionals. Human Resource Management, 41, 209-223.

11. Misra, P. (1998). Predictors of Work-family Conflict among Indian Women. Indian Journal of Psychology, 25(1), 13-19.

12. National study of Health and Wellbeing: Documentation of scales in MIDUS I. Midlife in the United States. University of Wisconsin, Institute on Aging. March 2004. Available at: http://www.midus.wisc.edu/midus1/documentationofscales.pdf. Accessed on April 2019.

13. Odle-Dusseau, H. N., Britt, T. W., \& Greene-Shortridge, T. M. (2012). Organizational work family resources as predictors of job performance and attitudes: The process of work-family conflict and enrichment. Journal of Occupational Health Psychology, 17, 28-40. doi:10.1037/ a0026428.

14. Russo, M. (2015). Work-home enrichment and health: An analysis of the mediating role of persistence in goal striving and vulnerability to stress. The International Journal of Human Resource Management, 26. Retrieved from: http://dx.doi.org/10.1080.

15. Sanz-Vergel, A. I., Rodreguez-Muoz, A., \& Nielsen, K. (2015). The thin line between work and home: The spillover and crossover of daily conflicts. Journal of Occupational and Organizational Psychology, 88 (1), 1-8. doi:10.1111/joop.12075.

16. Siu, O., Lu, J., Brough, P., Bakker, A. B., Kalliath, T., O’Driscoll, M. P., \& Shi, K. (2010). Role resources and work-family enrichment: The role of work engagement. Journal of Vocational Behavior, 77, 470-480. doi: 10.1016/j.jvb.2010.06.007.

17. Stamper, L.C., \& Johike, C.M (2003). The impact of perceived organizational support on the relationship between boundary spanner role stress and work out comes. Journal of management 29; 569.

18. Straub C, Beham B\& Islam G. (2017): Crossing boundaries: integrative effects of supervision, gender and boundary control on work engagement and work to-family positive spillover, The International Journal of Human Resource Management, DOI:10.1080/09585192.2017.1340324

19. Taylor, R. Delcampo and Blancero (2009). Work-family conflict/facilitation and the role of work place supports for U.S Hispanic professionals. J. Organiz. Behav.30, 643-664. DOI: 10.1002/job.605.

20. Van Steenbergen, E. F., \& Ellemers, N. (2009). Is managing the work-family interface worthwhile? Benefits for employee health and performance. Journal of Organizational Behavior, 30, 617-642. doi:10.1002/job.569.

21. Voydanoff, P. (2004). The effects of work demands and resources on work-to family conflict and facilitation. Journal of Marriage and Family, 66(2), 398-412.

22. Winslow, S. (2005). Work-family conflict, gender, and parenthood, 1977-1997.Journal of Family Issues, 26, 727-755. 
23. Yavas, U., Babakus, E., and Karatepe, O. M. (2008). Attitudinal and behavioral consequences of workfamily conflict and family-work conflict does gender matter? International Journal of Service Industry Management, 19, 7 